\title{
Up in the Air: I
}

\author{
ROBERT LORAINE
}

From Winifred Loraine, Robert Loraine: Soldier, Actor, Airman (London: Collins, 1938) pp. 90-1. Shaw went up in a balloon - the 'Norfolk', piloted by Percival Spencer - on 3 July 1906. His companions were his sister-in-law Mary Cholmondeley, Granville Barker and Robert Loraine, who left an account in his diary. It was this ballooning exploit that Shaw remembered when he told Charles Graves (brother of Robert) in 1929:

Personally I don't consider flying at all thrilling. The earth looks like one of those dreadful lithographic maps you see at the beginning of a directory. I expected also that the clouds would look as they do wreathing the feet of a Madonna in some old painting. In actual fact, of course, they are far beneath you. I know, because I once went up in a balloon.

When we reached 9,000 feet I found I was getting sleepy. That altitude seemed to have a deadening effect on the mind, at least in a balloon, although it might be different in an aeroplane. (Daily Mail, 19 September 1929)

'Ascending from Wandsworth Gas Works,' says Robert's diary, 'we were soon floating above the clouds at about 9,000 feet, exhilarated but somewhat awed by our first experience of altitude. After about forty minutes' drifting, very pleasant and seraphic with nothing happening, except that Shaw would peer through a hole in the boarding at his feet which made him feel rather sick, we discussed landing. We wondered what our reception would be on coming down in somebody's garden. I thought the people would be rather interested to receive visitors from the air, and especially flattered when they discovered Shaw's identity. "Don't be so certain," said Shaw. "They may think my works detestable." Mr Spencer, the aeronaut, assured us that no matter where we landed or who we might be, we should be overwhelmed by the warmth of our welcome owing to the unusual nature of our arrival.

'In due course we came down on a field near Cobham Common, and after assisting to deflate the balloon, we turned to find ourselves surrounded by people who seemed to have appeared from nowhere. We were just going to tell them all about it, when a purple-faced individual came rushing towards us waving a shooting-stick. This he had the grace to hide when he saw Mrs Cholmondely, but he was suffocating with fury, and the welcome he gave us was a curt direction as to the quickest way off his property.' 